\title{
Circuit
}

Musiques contemporaines

\section{[Sans titre]}

\section{Christopher Fox}

Volume 15, numéro 3, 2005

Souvenirs de Darmstadt : retour sur la musique contemporaine du dernier demi-siècle

URI : https://id.erudit.org/iderudit/902370ar

DOI : https://doi.org/10.7202/902370ar

Aller au sommaire du numéro

\section{Éditeur(s)}

Les Presses de l'Université de Montréal

ISSN

1183-1693 (imprimé)

1488-9692 (numérique)

Découvrir la revue

Citer cet article

Fox, C. (2005). [Sans titre]. Circuit, 15(3), 67-70. https://doi.org/10.7202/902370ar

\section{Résumé de l'article}

Participant aux cours de Darmstadt en tant qu'étudiant puis comme professeur, entre 1982 et 1994, le compositeur britannique Christopher Fox évoque les nombreux liens d'amitié qui se sont tissés dans cet endroit, et la vitalité des concerts qui y étaient présentés. Ces expériences l'ont amené à écrire sur le Darmstadt de l'époque Hommel, dont il a été le témoin de façon ininterrompue.
Ce document est protégé par la loi sur le droit d'auteur. L’utilisation des services d’Érudit (y compris la reproduction) est assujettie à sa politique d'utilisation que vous pouvez consulter en ligne.

https://apropos.erudit.org/fr/usagers/politique-dutilisation/
Cet article est diffusé et préservé par Érudit.

Érudit est un consortium interuniversitaire sans but lucratif composé de l’Université de Montréal, l'Université Laval et l'Université du Québec à Montréal. Il a pour mission la promotion et la valorisation de la recherche. https://www.erudit.org/fr/ 


\title{
SOUVENIRS
}

\author{
Christopher Fox
}

\section{1) What do you remember most about Darmstadt?}

I went to the Ferienkurse for the first time in 1982 as a 'Teilnehmer' and returned in 1984 and every two years after, until 1994, as a 'Dozent', so my memories of the place are complicated and multilayered. The most important memories are of discoveries, of music and of the people associated with it. It was not so much that I heard music there that I could not otherwise encounter but that in the hothouse atmosphere of the Ferienkurse the encounter was so much more intense. Particularly in 1982 and 1984, I gathered a host of ideas from Feldman, Grisey and Lachenmann especially, which have been part of my compositional thinking ever since.

In Darmstadt, I formed longstanding friendships with older composers - Walter Zimmermann and Clarence Barlow above all - and with composers of my own generation - Richard Barrett, Rodney Sharman, Linda C. Smith; in later years, relationships with younger composers and performers became more important, and my meeting with Richard Rijnvos and John Snijders, who I first met in Darmstadt in 1990, was of especial importance. Together they had created the Ives Ensemble, a collection of fine young Dutch musicians with whom I have worked ever since. We also shared a huge admiration for the work of Joseph Beuys and for the 'Block Beuys' which is a haunting presence in four rooms of the Hessisches Landesmuseum in the centre of Darmstadt. 


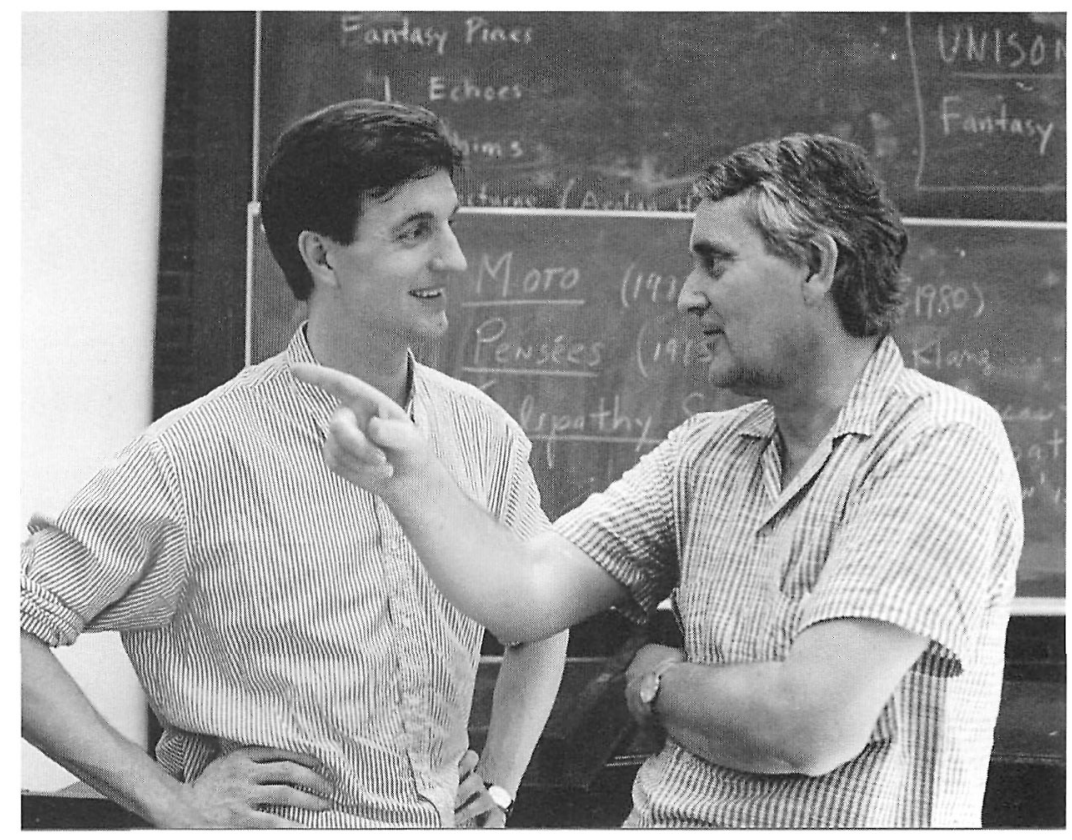

Christopher Fox: "This is a photo from the 1988 Ferienkurse. I am on the left, Friedrich Hommel on the right. Apart from reminding me that I once looked as young as that, I like it because it catches Friedrich's extraordinary benevolent energy, the force that drove the courses through the 80 's and go's and reestablished them as an important centre for new music. I also like the fact that although I have just finished lecturing on my own work, none of the titles on the blackboard behind us are of my music - indeed there are at least two different composers' handwriting there, evidence of the production line of composer presentations that were also a feature of the Hommel years. It has always seemed to me that the people who complained about the proliferation of guest composers during the 1982-1994 period, and would have liked a more exclusive focus on their work, tended to be those composers whose work lacked the distinctiveness necessary to survive in a more pluralist environment."

While I was involved in the Ferienkurse, Darmstadt was a sort of measuring stick in my life. Every two years I knew that I had to have some good new pieces for the concert series and had to be able to explain what I was doing to a fiercely critical audience in the lecture room. I loved being in an artistic climate where music generated such controversy and the response to my own works in concert - usually an invigorating mixture of cheers and boos - was a good measure of my success in treading the aesthetic path I had mapped out. I cannot imagine what my life as a composer would have been like without those seven biennial occasions when I was in Darmstadt for more or less all of the courses.

And I drank a lot of beer, enjoyed long breakfasts with my colleagues in the Hotel Maritim, ate lots of terrible food in the Georg-Büchner Schule, and 
spent many sunny afternoons (when I should have been listening to my colleagues) at the open air swimming pool just across the car park from the school.

\section{2) What does Darmstadt mean to you today?}

I last went to Darmstadt in 1996 , first to attend the opening of the exhibition Von Kranichstein zur Gegenwart (I was an editor of the book which accompanied the exhibition) and then for a weekend at the Ferienkurse to hear Hans-Ola Eriksson perform my organ music. My engagement with Darmstadt today is primarily historical. I have always been a composer who enjoyed writing about music as well as making it and before working on Von Kranichstein zur Gegenwart I had made a series of radio programmes for в в C Radio 3 on European avant-garde music in the period between 1945 and 1961, Music after Zero Hour, in which Darmstadt inevitably took centre stage. For a 1997 conference at the University of Mainz I wrote the paper "Darmstadt und der Mythos Modernismus" and for Contemporary Music Review I wrote an article on early Nono, in which Darmstadt also featured.

So I have become known as some sort of Darmstadt scholar. My presence throughout the Hommel Era means that I too am now part of the Ferienkurse's history, especially as I wrote articles about the courses in 1982, ' 84 and '86 and now I can observe (and occasionally participate in) the gradual formation of a Darmstadt history which is more or less congruent with my recollections of what the Ferienkurse were like between 1982 and 1994.

Inevitably, the period after 1996 is not so interesting for me. After 1988 , I think I had experienced enough Darmstadt not to need any more, although it was always a pleasure to be invited back, and I did feel distinct withdrawal pains in July 1998 when my compositional clock told me I should be in Darmstadt. I recommended a number of my students to go instead and kept in touch that way. I have also kept in occasional contact with Wilhelm Schlüter and on the European new music circuit there are always stories about who's in, who's out, what's happening. I have the sense that the Darmstadt I experienced was more anarchic than it is now but as long as Darmstadt continues to provide opportunities for musicians to get together and share music and ideas about music it will continue to be important. 


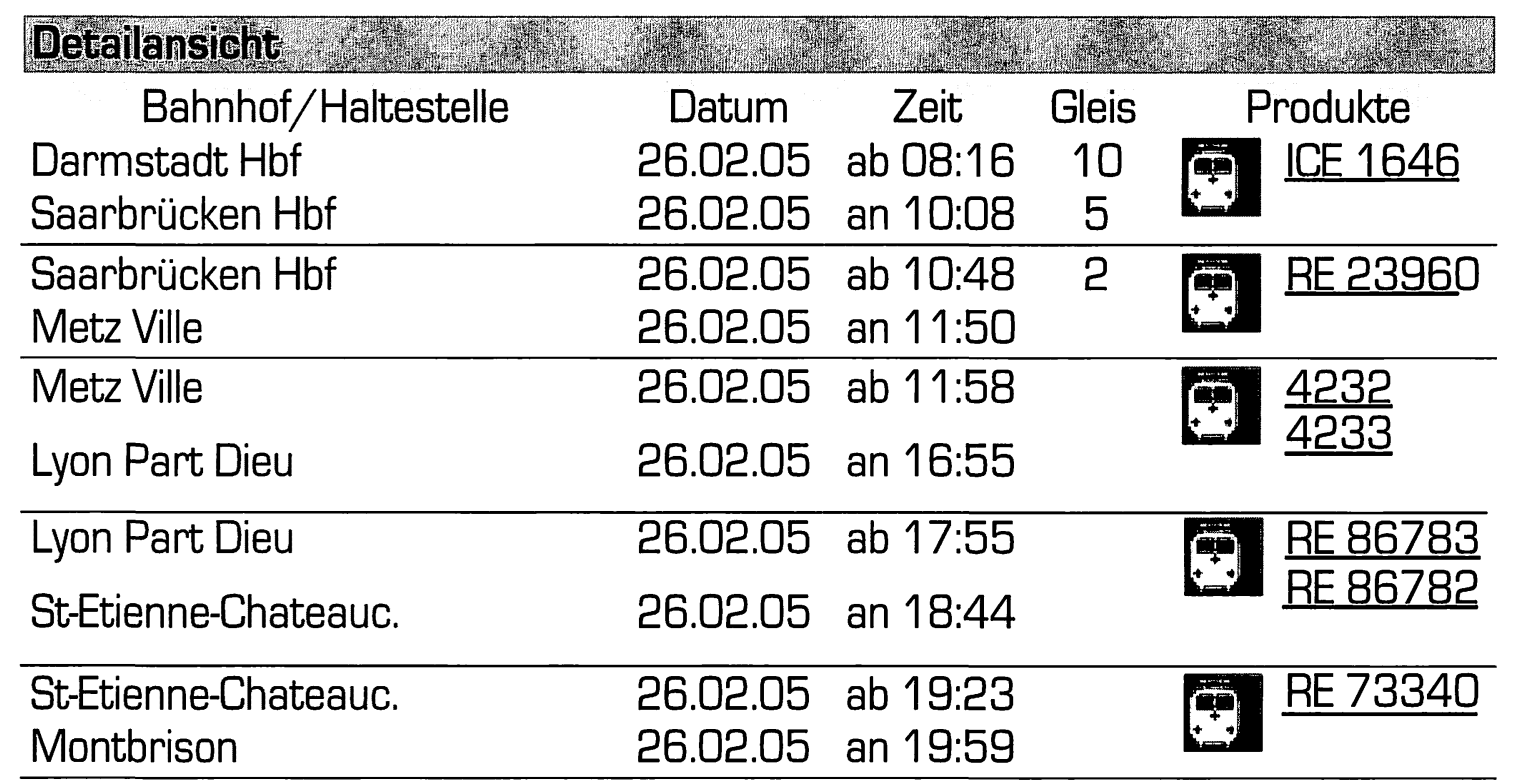

Dauer: 11:43; fährt nicht täglich, 26. Feb bis 11. Jun 2005 Sa Übg.: Forbach(fr) 